\title{
ESTUDO DOS EFEITOS DE BIOESTIMULANTES NA REPRODUÇÃO E CRESCIMENTO INICIAL DA PROGENNIE DE AVES TIPO CORTE
}

MOACIR OMENA DE OLIVEIRA

Orientador: Roberto Dias de Moraes e Silva

Disserłação apresentada à Escola Superior de Agricultura "Luiz de Queiroz", da Universidade de São Paulo, para obłenção do Título de Mestre em Nutrição Animal e Pasłagens.

$P \mid R A C I C A B A$

Esłado de São Paulo - Brasil

Agosło 1977 
A Maria José, minha mãe, semi-analfabeta e pobre, que, inexplicavelmente, soube, com tenacidade me conduzir à pös-graduacão.

A Vera Lúcia Benevides, minha esposa, sem cuja ajuda, não teria alcangado, nessa travessia, o fim colimado.

Aos Meus filhos, Gustavo e Jünior, bioestimulantes da minha jornada terrena.

Aos manos, Luiz, José, Reinaldo Iraci e Ivaniz do, pe?o incentino e confianca depositadas em mim. 


\section{A G R A D E C I ME N T O S}

Agradeço as seguintes pessoas e instituições:

Prof. Dr. Roberto Dias de Moraes e Silva;

Prof. Dr. Roberto Thomaz Losito de Carvalho;

Prof. MS. Joelito de Oliveira Rezende;

Prof. Dr. Celso Lemaire de Moraes;

Eng ${ }^{\circ}$-Agr ${ }^{\circ}$ Edimilsom Machado de Almeida;

Eng ${ }^{9}$-Agr ${ }^{\circ}$ Carlos Osvaldo Cardoso Pulici;

Eng ${ }^{\circ}$-Agr ${ }^{\circ}$ MS Ranulfo Correa Caldas;

Eng?-Agr? João de Souza Ávila;

Mêd. Vet. MS Luiz Gonzaga da Paz;

Sr. Märio Sperandio;

Sr. Josē Pedro Dias Maia;

Enfermeira Maria Angélica de Benevides;

Eng:-Agr? Jocelyn Santiago Brandão.

Conselho Nacional de Pesquisas (CNPq);

Granja ITO - Sumaré, SP.;

Laboratōrios Vitamínicos Valinhos Ltda.;

Universidade de São Paulo - Escola Superior de Agricultura "Luiz de Queiroz";

Universidade Federal da Paraíba - Centro de Ciências Tecno lógicas - Departamento de Zootecnia - Areia, Paraíba. 


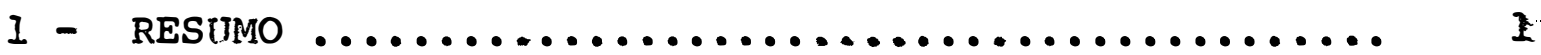

$2-$ INTRODUÇÃO $\ldots \ldots \ldots \ldots \ldots \ldots \ldots \ldots \ldots \ldots \ldots \ldots \ldots \ldots \ldots \ldots \ldots \ldots \ldots$

3 - REVISÃo DE LITERATURA $\ldots \ldots \ldots \ldots \ldots \ldots \ldots \ldots \ldots \ldots$

3.1 - Teoria dos bioestimulantes de FILATOV ..... 8

3.2 - Técnica utilizada na preparação dos extratos ......................... 10

3.3 - Emprego dos bioestimulantes ............ 15

3.3 .1 - Aves .......................... 15

3.3.2 - Mecanismos de ação dos bioestimulan tes ........................ 26

4 - METODOLOGIA .............................. 30

4.1 - Delineamento experimental ............ 32

4.2 - Preparação do bioestimulante .......... 32

4.3 - Materlal utilizado ................... 33

4.4 - Armazenamento ..................... 34

4.5 - Preparo do material para pesquisa ........ 34

4.6 - Esterilização e acondicionamento ......... 34

4.7 - Dados observados ................... 35

4.7.1 - Peso das aves ................. 35

4.7 .2 - Consumo de ração ............... 35

4.7 .3 - Produção de ovos .............. 35

4.7 .4 - Ovescopia .................. 36 


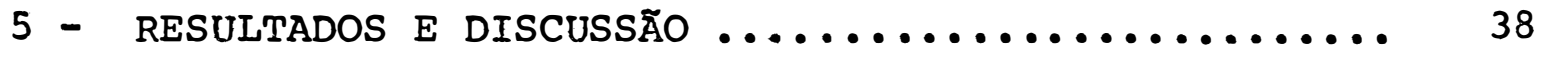

5.1 - Considerações gerais ................ 38

5.2 - Produção de ovos ................... 39

- 5.3 - Peso médio dos ovos .................. 41

5.4 - Incubabilidade total ............... 43

5.5 - Incubabilidade dos ovos férteis ......... 46

5.6 - Fertilidade ..................... 48

5.7 - Médi de peso dos galos em intervalos

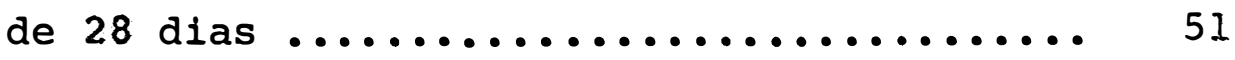

5.8 - Mëdias de peso das matrizes em intervalos de 28 dias ......................... 53

5.9 - Modias de peso da progênie aos 28 dias de idade .............................. 55

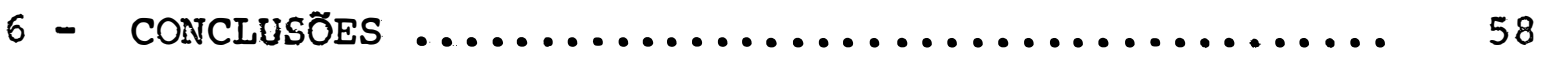

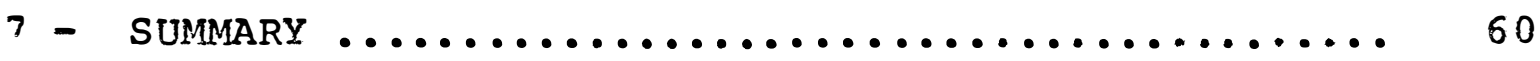

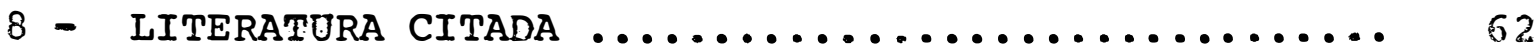




\section{INDICE DAS TABELAS}

Página

TABELA 1 - Média de produção de ovos por tratamentos e periodos .........................

TABELA 2 - Médiasde peso.dos ovos por tratamentos e pe-

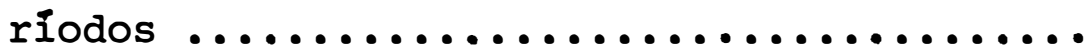

TABELA 3 - Médias da incubabilidade total por meses e

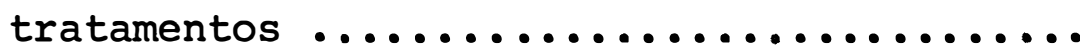

TABELA 4 - Médias da incubabilidade dos ovos férteis por tratamentos e períodos ..............

TABELA 5 - Médias de fertilidade de ovos férteis por tratamento e período

TABEla 6 - Médias de peso dos galos em intervalos de

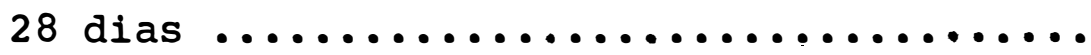

TABELA 7 - Médias de peso das matrizes em intervalos

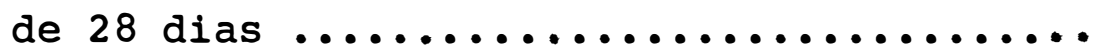

TABEla 8 - Médias de peso da progênie aos 28 dias de idade ......................... 
1 - RESUMO

0 presente trabalho visou estudar o efeito de bioestimulante (preparado de FILATOV) na reprodução de aves matrizes comerciais, tipo pesado e no crescimento inicial da progênie. Os experimentos foram realizados na Escola supe rior de Agricultura "Luiz de Queiroz", da Universidade de São Paulo, em Piracicaba, Estado de São Paulo, Brasil. A fase pré-experimental durou duas semanas e a experimental, dezoi to, ambas executadas de 28 de agosto de 1975 a 23 de janeiro de 1976 .

Foram utilizadas 200 matrizes e 20 galos da linhagem Hubbard. Os pintos nascidos de cada quarta incubação dos ovos das reprodutoras foram utilizados nos experimentos de crescimento. As matrizes receberam $150 \mathrm{~g}$ por cabeça por dia e os galos $200 \mathrm{~g}$ de ração de reproduçăo. Os pintos rece 
beram ração inicial "ad libitum". 0 experimento foi reali zado em parcela subdividida partindo do delineamento inteiramente casualizado, com cinco tratamentos, quatro repetições e dez matrizes e um galo por parcela. 0 tratamento 1 , atuou como testemunha e nada recebeu. 0 tratamento 2 , recebia três vezes por semana, vitaminas e aminoácidos solúveis (Aminoso1) sendo dosado $10 \mathrm{ml}$ do produto por litro déágua, por parcela. Os tratamentos 3,4 e 5 receberam separadamente I ml de bioestimulante injetado no peito da ave, a cada 7,14 e 21 dias de intervalo, respectivamente. No início do experimento e a cada 28 dias, as aves eram pesadas. 0 bioestimu lante foi preparado com hipófises, suprarrenais e testículos bovinos conforme método desenvolvido por FILATov. 0s ovos produzidos eram colhidos quatro vezes por dia, por parcela, pesados e fumigados. Ao 180 dia era feita a ovoscopia e ao 219 dia os pintos nascidos eram pesados por parcelas sendo anotados também ovos picados, pintos mortos e refugos.

As médias de produção de ovos não foram afetadas pela utilização de bioestimulantes, ou aminosol, mas houve significância estatistica, ao nível de $5 \%$ de probabilidade, d:s médias entre períodos.

As médias de pesos dos ovos não foram influenciados nem por tratamentos, nem por períodos.

As médias de incubabilidade total não tiveram res postas estatisticamente sigrificativas quanto a tratamentos. Apresentaram, porém, efeitos entre periodos $(P \geq 0,05)$. 
As médias de fertilidade não apresentaram significância estatística quanto a tratamentos, sendo, não obstante, significativas estatisticamente ao nível de $5 \%$ de probabilida de, entre períodos.

As médias de pesos dos galos e matrizes, em intervalos de 28 dias e as médias dos pesos iniciais da progênie, aos 28 dias de idade, não apresentaram significância estatística nos tratamentos, mas apresentaram entre periodos $(P \geq 0,05)$. 
Alimentar a humanidade, é, no momento um dos grandes desafios do mundo moderno, desde que não são alentadoras as pers pectivas futuras nesse campo.

A proteina é escassa, notadamente a de origem animal, sendo que para produzi-la economicamente se torna imperioso reduzir-se o seu custo de produção. Daí se tem dado atenção, desde hà alguns anos, ao aumento de produtividade em bovinos e outras espécies animais, dando-se ênfase especial ao incremento ponderal. Para tanto, a Zootecnia tem procurado utilizar, dentre outros recursos o uso de aditivos e dentre esses, os esti mulantes de crescimento.

A avicultura como produtora de proteina animal, tanto quantitativa como qualitativa, em termos de menor sempo e paço é um setor zootécnico decisivo para minimizar a carência protéica ora existente. 
Existem centenas de aditivos usados na pecuária, es pecialmente antibióticos.

Muitos destes produtos, a maioria sintética, a par de trazer beneficios tem encarecido a produção, e, o que é pior trazido problemas de toxicidade residual para os consumido res, FAO (1969) e GUILlAUME e CALET (1972).

Tentando diminuir ou mesmo extinguir tais proble mas, cientistas de diversos paises e especialmente do Leste europeu, notadamente os soviéticos, vem desenvolvendo hä décadas, pesquisas para a utilização de extratos de tecidos de animais para usos veterinários e humanos, na terapia, profilaxia e espe cialmente no campo da nutrição animal.

Por volta de 1930, o Professor WLADEMIR filatov, mé dico oculista russo, iniciou uma série de pesquisas nas quais fazia enxertos em olhos de pacientes de pedaços de córneas reti radas de ćadáveres. Encorajados pelos primeiros resultados, FILATov supôs que fragmentos de tecidos de diversas naturezas pudessem ter a mesma finalidade. Assim, testou tecidos cartilaginosos, musculares, glandulares e epiteliais em seus pacientes. Depois de alguns anos de sucessos nas suas pesquisas, FI LATOV procurando explicação para esses benéficos efeitos, criou sua teoria denominada "TEORIA BIOGENICA DE FILATOV". De acordo com essa teoria, as células dos tecidos animais, quando sepa radas dos tecidos originários e submetidas às condiçôs desfavo ráveis de sobrevivência (baixa temperatura e obscuridade), que tornam dificeis os processos metabölicos vitais, sofrem um pro- 
cesso de transformação bioquỉmica, dando como consequência, com postos não identificados, os quais estimulariam os processos vi tais e por isso mesmo denominados "estimulinas biogênicas".

Segundo IOPA e MANOV (1958), pela explicação de FILATOV, qualquer tecido de organismo vivo, separado deste e gua dado em condições adversas, porêm não mortais, na luta pela sua sobrevivência, modifica-se bioquimicamente, produzindo substâncias especîficas, tais como estimulinas biogênicas, que mantém relações vivas nestes tecidos isolados, protegendo-os contra morte räpida. Segundo o mesmo autor, FILATov definiu muito bem os bio-estimulantes com a seguinte frase: "Em todo lugar onde se aproxima a morte, surgem os estimulantes, ültimo recurso da vida que foge".

Sendo introduzidas no organismo, estas substâncias estimulariam diversas funções, aumentariam a resistência contra fatores negativos do meio e estabeleceriam o retorno rápido das cordições normais dos örgãos ou sistemas enfermos.

Na formulação da sua teoria, FIlATov deu em outra parte, ampla ênfase à técnica de preparação do material emprega do para as intervenções cirúrgicas que seriam por ele feitas.

Imediatamente após a publicação da teoria biogênica os implantes de diversos tecidos foram utilizados de maneira crescente na medicina humana.

Muitos anos depois, os resultados encontrados por FILATOV e seus colaboradores, quando comparados com resultados de pesquisadores europeus mostraram algumas contradições. 
Estas contradições eram provavelmente devido à falta de conheci mento sobre as técnicas de preparação, bem como, o desconheci mento da natureza dos estimulantes biogênicos (BOSCHI e GASPARI, 1959). O próprio FILATov, no início, acreditava que estes com postos eram semelhantes aos ácidos aromáticos e nucléicos.

Por muitos anos nenhum investigador conseguiu identificar estes compostos. As estimulinas biogênicas, referidas por FILATOV, são denominadas prostaglandinas.

No setor pecuário nacional, a criação de aves, nos ültimos lustros experimentou notável avanço tecnológico em rela ção à bovinocultura, suinocultura e outras espécies de animais domésticos.

As granjas de matrizes são responsāveis pelo fornecimetto de aproximadamente 35 milhões de pintos de corte por mês. As granjas avozeiras, fornecem, anualmente, mais de seis milhões de matrizes de corte.

Hâ grande desperdício de glândulas e outros órgãos nos abatedouros, além de embriões de animais, sangue, placentas dos nascimentos das grandes criaçoes industriais, confinadas ou semiconfinadas de suinos e bovinos. Destes materiais são confeccionados os preparados de FILATOV, constituindo-se, assim, em fonte de matéria prima barata.

Este trabalho visou estudar o efeito de bioestimu lante (preparado de FILATOV) na reprodução de matrizes comerciais, tipo pesado e no crescimento inicial da progênie. 


\section{1 - Teoria dos Bioestimulantes de FILATOV}

BERGSTROM e SAMUELSON (1965) informaram que em $1933 / 1934$ GOLBLAT e VON EULER, independentemente, demonstraram que extratos de plasma seminal humano e da glândula vesi cular de carneiro produziam uma queda da pressão sanguínea e estimulavam uma variedade de músculos lisos e örgãos. 0 material ativo foi chamado prostagandina, por VON EULER pensan do tratar-se de substância exclusiva da próstata que foi demonstrado pelo cientista, ser um lipideo solúvel, com proprie dades àcidas.

Hoje se conhecem cerca de 14 espécies de prosta glandinas e que são secretadas pela maioria das células do corpo. Estas substâncias são identificadas por letras: PGA, $P G B$, etc., atê $H$, com subtipos como $P G_{2}^{-a l f a . ~ S e u s ~ e f e i-~}$ 
tos são muitas vezes opostos.

PETRUSKIN e DAHKILJGOVA (1961), realizaram inúmeros experimentos nos anos de $1959 / 1960$ nos quais forneceram prepara dos de tecidos animais a diversas espécies incluindo aves, para fins terapêuticos e profiláticos, tentando ainda promover ganho de peso e postura.

WOOD e WORDEN (1963), informaram que só em 1963 , mais de 100 mil toneladas de alimentos para vacas leiteiras foram suplementados com Hormonexa, produto feito de tecido glandu lar composto de fígado seco de bovino, baço, feto, estômago e placenta misturados à base vegetal e mineral.

De acordo com CARVALHO (1971), com a precipua finalidade de encontrar compostos que apresentassem efeito bioestimulante e cujo custo de produção fosse suficientemente econômico, estudiosos iniciaram pesquisas sobre extrato de tecido animal, tendo idó FILATOV o primeiro a criar uma técnica de preparação e a produzir um extrato hepático de bovino que apresentava ação bioestimulante.

IOPA e MANOV (1958), realizaram diversos experimentos com o bioestimulante de FIlATov informando que era fácil o seu preparo, baixo o seu custo e apresentavam resultados satisfatörios.

Com base nos trabalhos de FILATov vários pesquisado res europeus prosseguiram os estudos sobre a teoria bioegênica do autor russo, destacando-se ZABOLOTNYS (1958), TOROSIAN (1959), KALASNIK (1960) e SHALATOV (1964). 
PHARRIS e SHAW (1974), fizeram comunicação sobre a ocorrência de prostaglandinas, distribuição nos tecidos, biossintese, metabolismo, fisiologia e farmacologia, indicando ain da uma vasta lista de trabalhos até agora publicados sobre o as sunto.

\section{2 - Técnica Utilizada na Preparação dos Extratos.}

MARY e GUSTAVSON (1930), utilizaram preparado de placenta humana para estudar resposta na produção de caracte res subsidiărios da genitāila de aves fêmeas e plumagem. A placenta humana, após remoção de membranas e tendões foi tritu rada num moedor de carne. Colocou-se 1,5 litro de álcool etí lico para cada quilo do material. Todo material era totalmen te misturado, ficando em repouso durante una semana e depois filtrado em algodão. Ofiltrado foi evaporado sob baixa pres são ficando uma solução aquosa turva com volume de 25 cc. A parte turva foi retirada com benzeno e as camadas separadas. o efeito do preparado placentärio humano sobre o oviduto de frangas foi estudado em três diferentes tipos de experimentos. Em dois deles, foram obtidos resultados positivos: os ovidu tos das frangas testadas mostraram uma aumento dez vezes maior nos ductos, em relação aos das testemunhas. Notou-se ainda, aparecimento de glândulas tubulares e tecido musculoso, estruturas estas ausentes nos animais testemnnas. 
JAAP (1935), utilizou extratos de pituitária de pato e de galinha para estudar a potencia estimuladora gonadal de pituitárias individualmente, em pintos, patos e ratas jovens. Todas as pituitärias foram colocadas em acetona imediatamente a pós serem removidas da cabeça das aves doadoras. Quando estavam inteiramente dissecadas, foram pulverizadas e colocadas em solução, usada para injeção.

o método original proposto por fILATOV descrito por IOPA e MANOV (1958) foi o seguinte: o fígado de um bovino recém abatido era mantido por 4 a 5 dias até uma temperatura de 09 a 5:C, sendo finalmente picado e homogeneizado em solução salina fisiológica, na proporção de $1: 2$. Em seguida era escaldado a $809 \mathrm{C}$ durante uma hora e meia. 0 material era res friado e depois filtrado. 0 filtrado era colocado em autoclave por uma hora, a $1009 \mathrm{C}-1209 \mathrm{C}$.

ZAMBOLOTNYS (1958), constatou que a mistura de teci dos de bovinos possui efeito estimulante análogo ao do fígado e que a homogeneização, em solução fisiológica, podia ser feita na proporção de $1: 3$.

0 mesmo autor preparou extratos de tecidos conser vando as peças durante uma semana, a uma temperatura de $20 \mathrm{C}$ a 40. - Fez homogeneização do material na proporção de $1: 3$ com solução salina, depois guardou por uma hora numa estufa e em se guida aqueceu durante uma hora. Estocou em ampolas e autoclavou. Os tecidos utilizados foram fígado e baço bovinos. 
TOROSJAN (1959) preparou um estimulante biogênico denominado Antiseptik Dorogava (ASD FR-2) utilizando tecidos $\underline{a}$ nimais, vegetais e microbianos. 0 extrato daí resultante foi usado em diluição de 1:20 para aplicação intravenosa em animais.

KOROL'KOV e PETRISIN (1960), em experimento realizado com o fim de confrontar os efeitos do bioestimulante obti do de tecido de testículo e de extrato de fígado, verificou a melhor eficácia do extrato hepático.

DOROSKOV (1962), utilizou amostras de tecidos placentários, obtidas de vacas, ovelhas e porcas no parto. Utilizou os mesmos tecidos, após o abate de éguas, vacas, ovelhas e porcas, em diferentes estägios de prenhez. A atividade biológica dos extratos usando o método de FILATOV foi testada para observar efeitos estimulantes sobre o crescimento de leveduras. Os extratos preparados em ägua comum ou soluçãofisiológica salina foram melhores do que os feitos com água des tilada. Para todas as espécies os melhores períodos de armazenamento dos tecidos entre $2 \circ \mathrm{C}$ e $4 \circ \mathrm{C}$ durante a preparaça foi de cinco para seis dias. Nas espécies estudadas, a placenta foi mais ativa do que as membranas. Os tecidos nos quais se encontraram mais alta atividade, foram placentas de vaca e ove 1ha, sendo que, esta atividade aumentou ainda mais, quando os extratos foram autoclavados a 120 :C por uma hora. 
MARAKOV e SOLOVEN (1962), procederam a uma modificação no método de preparação de tecidos de filltov. Colhe ram tecido fresco de baço guardando-o por quatro ou cinco dias a uma temperatura entre $29 \mathrm{C}$ e $49 \mathrm{C}$. 0 tecido foi então picado e misturado com duas vezes o seu volume em solução fisiológica salina, fervido por duas horas, coado, filtrado e misturado com agar-agar. 0 preparado foi engarrafado e esterilizado. Os autores informaram ainda que boas preparações possuiam 3 a $3,5 \%$ de matéria seca, e 1,8 a $2 \%$ de proteína. 0 preparado foi injetado em suínos numa dose de 0,2 ml por kg de peso vi vo. 0 extrato feito com agar-agar mostrou-se mais efetivo em bovinos e suínos do que os extratos convencionais de FILATOV. MARGARET (1967) visando estudar a estimulação do ovārio em galinhas hipofisectomizadas, utilizou extrato seco de pituitäria, assim preparado: glândulas pituitärias do lóbu 10 anterior foram coletadas de frangos de ambos os sexos com 8 a 12 semanas de idade, secadas em acetona e moídas. A média de produção do material seco por glândula foi $1,2 \mathrm{mg}$. 0 pó em vārias concentrações foi suspenso em solução salina isotônica, e a dose injetada em aves foi de $1 \mathrm{ml}$. Concluiu a au tora, pelos resultados do experimento, que em galinhas hipofisectomizadas, com regressão do ovärio, o desenvolvimento folicular e secreção de hormônio podem ser restaurados através de tratamento com extrato de glândula pituitária de aves. 
GONDOS et alii (1968) utilizaram experimentalmente seis bioestimulantes nativos em função do substrato, nos quais estão englobadas as substancias ativas. Os substratos utilizados foram: levedura forrageira, farelo de trigo, calcáreo, farinha de alfafa, "maize draff" e farelo de milho. Após seis meses, a máxima conservação das vitaminas $A, E, B_{1}, B_{2}$ e niacina foi registrada com os substratos de levedura, farelo de trigo e calcário. 0 mínimo foi com o substrato de farelo de milho, sendo os mais econômicos, levedura e farelo de tri go.

Os mesmos autores com o fim de estabelecerem a efi ciência de diferentes substratos para fabricação de bioestimulantes rumenos em comparação aos bioestimulantes importados, $\underline{e}$ fetuaram dois experimentos com aves. Constataram que o máximo de conservação das vitaminas $A, E, B_{1}, B_{2}$ e niacina durante seis meses para os estimulantes nacionais ocorreram com levedura, calcário e farelo de trigo, Com os preparados estrangeiros, o conteūdo de vitamina $A$, após seis meses de conservação estava integro e, de acordo com a bula (fórmula). A economicidade foi maior com substratos de levedura e farelo de trigo.

KIYOSHI (1973) verificando efeitos de preparados de pituitārias de mamíferos e aves sobre o desenvolvimento folicular em galinhas tratadas com metalibure e em regime de res trição alimentar total, utilizou o seguinte método para obter 
os preparados glandulares: pituitārias da glândula anterior de aves (CAP) foram coletadas de frangos de ambos os sexos, armazenadas por curto espaço de tempo a - 209C. A CAP foi homogeneizada em solução salina fria e colocada num recipien te contendo gelo antes de ser injetada. Parte deste preparado foi armazenado durante duas semanas em acetona fria substituindo com acetona fresca, cada três dias, e depois secada e colocada em um dissecador. A CAP seca foi então homogeneizada em solução salina fria antes de ser utilizada injetável.

3.3 - Emprego dos Bioestimulantes.

\section{$3.3 .1-\underline{\text { Aves }}$}

BEGALINBSKI, citado por IOPA e MANOV (1958), aplicou em 257 patos doentes, um bioestimulante na dose de $1 \mathrm{ml}$, quatro vezes, com intervalo de cinco dias, obtendo após a primeira aplicação, melhora de apetite, atitude ativa e no final do tratamento as aves melhoraram totalmente o empenamento e cessou completamente a mortalidade.

$$
\text { PETRUSKIN e DAHKILJGOVA (1961) forneceram } 1 \mathrm{ml}
$$

por ave de bioestimulante, diariamente, durante quatro dias a 1.000 poedeiras, divididas em 500 tratadas e 500 não tratadas. o tratamento foi repetido quatro vezes com intervalos de sete dias. As aves tratadas superaram em $11,3 \%$ a produção de o- 
vos das testemunhas e no periodo experimental a mortalidade das aves tratadas foi de $5,8 \%$ contra $9,2 \%$ das que não receberam bio estimulantes. $0 s$ mesmos autores repetiram o experimento, utilizando 14.000 galinhas não confinadas, fornecendo $1 \mathrm{ml}$ de bioestimulante por ave. As aves,no inicio do experimento, tinham em média, $32 \%$ de postura e empenamento deficiente. Após três períodos de aplicação do preparado a postura aumentou em 30 a 40 dias, 70 a $80 \%$, notando-se a melhoria do empenamento e aumento do apetite das aves. Em seguida os autores conduziram experimento com 5.500 marrecos de postura que receberam bioesti mulante, conseguindo no fim do ensaio 30 a $80 \%$ no aumento de postura e maior atividade sexual dos machos.

$$
\text { JULENKO (1958), citado por BOCAROVA (1966) aplicou }
$$

preparado "SB" (soro sanguíneo de proteina desnaturada) em aves reprodutoras. 0 soro foi injetado por via intramuscular em dose de $4 \mathrm{ml}$ por ave, três vezes, em dias alternados. Os re sultados obtidos demonstraram ter havido estimulo da função sexual, aumento da postura em $14,2 \%$, no mês seguinte à aplicação. Houve também melhora em $10 \%$ da incubabilidade. Doses maiores tiveram efeitos adversos.

BOCAROVA (1966) efetuou experimento utilizando reprodutores que receberam preparado "SB" (soro sanguíneo). 0 en saio efetuado envolveu 38 reprodutoras da raça moscovita branca, com um ano de idade. As aves foram divididas em quatro grupos, apös dois meses de prē-experimento, de acordo com postü 
ra e peso de ovo, sendo três grupos experimentais que recebiam, respectivamente, 2,4 e $6 \mathrm{ml}$ por ave do bioestimulante e o quarto grupo testemunha, nada recebendo. A aplicação do "SB" a galos e galinhas era intramuscular, três vezes em dias alter nados. Baseando-se nos resultados dos experimentos o autor concluiu que doses adequadas do bioestimulante em reproduto ras aumentaram postura, incubabilidade e qualidade da progênie. A dose ideal foi $2 \mathrm{ml}$ por ave aplicada três vezes promovendo um aumento de $11,6 \%$, em média de postura, em três vezes e a eclodibilidade em $10,3 \%$. Doses de $6 \mathrm{ml}$ inibiram a postura e ferti lidade dos ovos, o que está de acordo com pesquisas anteriores de JULENKO (1958), citado por BOCHROVA (1966).

GRANAT et alii (1964) testando velocidade de ciescimento em frango de corte, num período de 110 dias, não encon traram diferença significativa, quando aplicaram nas aves dose de $0,5 \mathrm{ml}$, em intervalo de $10 \mathrm{dias,}$ com extrato de baço ou de testiculo.

Contudo, OE et alii (1966) forneceram a pintos, doses de 0,5 a $1,0 \mathrm{~m} 1$ de preparado de tiróide (I. C. E.) e a conversão das aves tratadas foi superior em 82 a $93 \%$ às teste munhas, aos 50 e 60 dias. Aos 47 e 61 dias o ganho de peso e ra de 14,02 e $13,11 \mathrm{~g}$ para as aves que receberam doses de 0,5 e $1,0 \mathrm{~m} 1$ do preparado.

VORONEDOV e NEFEDOV (1966) utilizaram 100 frangos, durante 23 dias fornecendo, a cada ave, 2 m1 de preparado de 
baço de bovino, cinco vezes, com intervalo de três dias e, em seguida, forneceram a outras 100 aves, 4 ml do mesmo prepara do, conseguindo um ganho de peso de, respectivamente, 265 e 2538 .

Prosseguindo os estudos acerca do emprego do preparado "SB" em avicultura, BOCAROVA (1967) estudou a ação des te bioestimulante sobre os embriões, pintinhos e galinhas adultas, bell como a técnica exata da sua aplicação e dosagem. Os estudos revelaram que:

a - A injeçāo do preparado heteroproteico "SB" no ovo não es timula o desenvolvimento embrionārio e por outro lado es ta prätica é inviável na moderna incubação;

b - A injeção subcutânea em pintinhos de dez dias na dose do $0,008 \mathrm{mg} / \mathrm{g}$ de peso vivo, influia no seu crescimento e de senyolvimento.

c - A injeção de "SB" no músculo peitoral das reprodutoras na dose de $1 \mathrm{ml} / \mathrm{kg}$ de peso vivo estimulou os processos de troca, aumentando a postura, incubabilidade e qualidade dos pintinhos;

d - A ação do preparado "SB" sobre o organismo da ave é de curta duração.

ROGOZIN e RADKEVIC (1967) estudaram a influência do hormônio anabólico fenil-propionato-d1-19-nor-D-homo-testosterona e preparado de tecidos embrionários secos, sobre o crescimento de frangos de corte, provenientes de cruzamento de Sussex $x$ Vermelha de Rabo Branco. Os pintinhos experimen 
tais foram selecionados aos 13 dias e divididos em um grupo tes temunha, um grupo que recebia hormônio injetävel por via intramuscular e a um terceiro grupo o qual foi fornecido o preparado de embrióes misturado à ração. 0 hormônio era diluído em óleo de pêssego e aplicado aos pintinhos na dose de 1,2 mg/kg de pe so vivo, sendo $0,2 \mathrm{ml}$ aos $13 \mathrm{dias}$ de idade, $0,4 \mathrm{ml}$ aos dias e $0.5 \mathrm{ml}$ aos $73 \mathrm{dias}$. O preparado de tecidos era forneci do diariamente com a ração na dose de $0,2 \mathrm{~g} / \mathrm{kg}$ de peso vivo durante todo o período experimental. 0 peso vivo médio das aves tratadas (com exceção do grupo 2 , aos 30 dias de idade) foi sü perior ao testemunha durante todo o período do experimento e no 908 dia, a diferença por ave foi de $79,7 \mathrm{~g}$, no grupo 2 , e $46,5 \mathrm{~g}$, no grupo três. Os aumentos dos pesos médios desde o início do experimento até o 900 dia foram superiores às testemunhas em 4,2 e $2,4 \%$. Os autores, pelos resultados conseguidos chamam a atenção para o detalhe de que os acréscimos de peso dos pintinhos do terceiro grupo, até o 50 Q dia de idade foram superiores aos do segundo grupo. Posteriormente os acréscimos de peso dos pintinhos do segundo grupo,superaram quase em duas vezes os dos pintinhos do terceiro grupo. Para os autores, a dinâmica dos acréscimos de pesos médios nos grupos testes indica que periodos de crescimento intenso se alternam com periodos de crescimento mais lento.

GORLOVA (1971), testou em grupos de 240 aves por tratamento, $\operatorname{com} 20$ a 60 dias de idade, um extrato de tecido. 
As aves tratadas compreendiam cinco tratamentos e a testemuna, era o sexto tratamento. As doses empregadas foram 0,05 e 0,2 de tecido por kg de peso vivo misturadas à dieta e para dois grupos foram fornecidas injeçôes simples de 2 e $4 \mathrm{mg}$ a testosterona por kg de peso vivo. Comparados com os contro les, houve maior aumento com 2 mg de testosterona (19\%). 0 maior aumento ocorrido com preparado de tecido (6\%) ocorreu com a dose de $0,2 \mathrm{mg}$.

\section{PALAMARU et alii (1968) experimentaram diferentes}

preparados de bioestimulantes rumenos e importados, em pintos de corte e poedeiras a fim de estabelecer as suas eficácias sobre a produção (aumento de crescimento nos primeiros e quantida de de ovos nos segundos), bem como, a velocidade de perda de di ferentes vitaminas que entram na sua composição, particularmente as lipossolúveis. Ho expeirmento que durou 75 dias os pintos tratados apresentaram-se com 15,1 e $19,5 \%$ de peso corporal médio superior à testemunha. A economia de alimento por kg de peso vivo ganho foi de 17,4 e $22,9 \%$. 0 preço de alimento con sumido pelos lotes experimentais por $\mathrm{kg}$ de aumento de peso vivo foi de $3,3 \%$ a $16,9 \pi$ menores que o do lote testemunha. Entre as poedeiral tratades o anmento de ovos fol 11,8 13,32 euperior às năo tratadas. O consumo de raçăo para obter dez ovos foi 3,8 a $7,9 \%$ mais reduzido do que para a testemunha. Por outro lado, a taxa de eclosão e o conteüdo en vitamina dos ovos foram mais elevados nos animais que receberam bioestimulante. 
SOKOLOVA (1971) forneceu a 250 aves um preparado de tecidos só, preparado de tecidos mais suplemento da dieta e a testemunha (sem preparado e suplemento). As aves que receberam só o preparado, após 60 dias, tiveram um ganho de peso de $14,3 \%$ superior às testemunhas. Estes resultados foram con firmados por uma etapa de um ensaio similar quando suljumova (1971) em experimento envolvendo 1.200 pintos e 4.992 poedei ras, encontrou que o peso vivo das aves que receberam só bio estimulante excedeu ao da testemunha em 21,5 e $23,3 \%$, nos primeiros trinta dias de vida e em 10,8 e $11,1 \%$ nos trinta dias seguintes. Nos três experimentos com poedeiras, as aves recebendo $1 \mathrm{~g}$ de bioestimulante diariamente, tiveram um au mento de 13,9 e $19,3 \%$ na postura, em relação à testemunha. 0 peso dos ovos das aves que receberam o bioestimulante foi de $57,5,51,2$ e $53,0 \mathrm{~g}$, versus $55,5,48,3$ e $52,0 \mathrm{~g}$ das testemunhas.

A eficácia do bioestimulante com inclusão de outros aditivos à raçäo foi reafirmada por KOVBASSENKO (1968) que conduziu uma série de três experimentos visando verificar - efeito de alguns preparados de tecido seco, vitamina ${ }_{12}$ concentrada e sua combinação com antibióticos sobre a qualidade de ovos de poedeiras comerciais e reprodutoras. 0 forneci mento de 1 g diário de preparado de tecido seco aumentou o peso do ovo de 2,0 a $5,8 \%$ comparado aos controles que não recebe ram tratamento. A eclodibilidade dos ovos postos por reprodu toras que receberam um suplemento de vitamina ${ }_{12}$ foi de $82,2 \%$ 
versus, $76,1 \%$ para os ovos das aves sem suplemento.

A comprovação da melhor eficiência do bioestimulan te seco quando combinado a aditivos suplementares è evidenciado por mais um trabalho de KOVBASSENKO (1969) em que o autor procurou estudar a influência do preparado de tecidos secos, não aproveitados na alimentação, combinados à biomicina, sobre a alteração do aspecto exterior de frangos de corte. Entende - pesquisador que com a idade deve ser aumentada também a dose do aditivo (BKV), concluindo, ainda que:

a - Pintos de 10 a 30 dias de idade suplementados com ração contendo bioestimulante e biomicina melhoram o seu cres cimento.

b - Bioestimulante mais biomicina mais ração aumentam os ín dices externos de pintinhos, a medida que aumenta o seu peso vivo.

c - No caso de pintos da raça russa branca com 10 a 30 dias de idade o mais indicado foi fornecer $0,5 \mathrm{~g}$ de preparado de tecido seco acrescido de dose completa de BKV.

KOVBASSENKO (1970) estudou a alteração dos ovos e carne de poedeiras sob a influência de doses de bioestimulan tes de tecidos secos provenientes do resto de abate de animais. Foram utilizadas 4.172 poedeiras da raça russa branca com idades variando entre 8 e 18 meses. 0 grupo teste recebia $1 \mathrm{~g}$ por ave por dia de bioestimulante mais ração e a testemunha, só ração. 0 experimento revnlou que a postura do grupo trata 
do foi bem superior ao controle nas três repetições em $20,5 \%$ na quantidade de carne e $3,8 \%$ no peso de ovos. Em comparação ao grupo controle os carotenóides se elevaram em 8,32 microgra mas por ovo e por conseguinte, houve melhora na classificação. KRASIL'NIKOVA (1970) estudou a influência do bioes timulante seco de tecido embrionärio em 1.582 poedeiras. pesquisa consistia de duas partes: na primeira era determinada a dose mais ativa do estimulante para as aves e, na segunda - efeito do bioestimulante na postura.

Galinhas de ambos os grupos tiveram um aumento de peso em média, de $100 \mathrm{~g}$ por cabeça. Com dose de $0,2 \mathrm{~g}$ a postura foi igual à testemunha e com $0,3 \mathrm{~g}$ de bioestimulante a postura superou à testemunha. 0 peso das galinhas diminuiu, e a postura foi idêntica às testemunhas. Foi observado um de créscimo de peso nas galinhas equivalentes a 124 g por cabeça em média. A postura foi maior que nas testemunhas.

As galinhas que receberam o estimulante na dose de 0,3 por cabeça apresentaram postura mais elevada. 0 peso das galinhas diminuiu. Consequentemente o bioestimulante seco na dose de $0,5 \mathrm{~g}$ por cabeça não apresentou atividade estimulante sobre as galinhas. 
0 aumento da dose atē 1 g por cabeça, provocou diminuição da quantidade dos elementos básicos do sangue e uma perda de peso ainda maior nas galinhas. Desta forma, o bioestimulante seco, de tecido embrionärio na dose de $1 \mathrm{~g}$ por cabeça apresen ta uma ação inibidora sobre as galinhas. Os resultados das presentes pesquisas coincidem com os trabalhos de outros auto res. Assim, XAITOV (1966), estudando a ação de diferentes do ses de preparados de tecidos feitos de baço e fígado de gado sobre as coelhas, constataram que o estimulante em doses mais altas não apresentaram influência estimulante substancial e até impediam o crescimento das coelhas. Esse autor chegou à mesma conclusão, durante o estudo da influência do estimulante feito de baço sobre os bezerros. Ele afirmou que o melhor efeito estimulante do preparado de baço foi obtido com dose de $4 \mathrm{ml}$. Doses de preparado de tecidos, superiores a $4 \mathrm{ml}$, não acusaram efeito estimulante.

Resultados semelhantes obteve ZINCTHENKO (1966) ve rificando a influência do estimulante sobre os leitões. Baseando-se no acima citado, o autor pôde concluir que a dose mais ativa para as galinhas do estimulante biogênico seco, fei to de tecido embrionário foi $0,3 \mathrm{~g}$ por cabeça.

Utilizaram de 3.200 galinhas, estas foram divididas em 1.550 testemunhas e 1.650 experimentais. No periodo preparatörio a alimentação e a manutenção das aves eram idêntị cas. Na fase pré-experimental foram verificados: peso das a ves, quantidade e peso dos ovos, quando, também foram achados 
iguais resultados para tratamentos e testemunha. Na fase experimental, que durou três meses as testemunhas receberam estimulante de tecido embrionário na dose de $0,3 \mathrm{~g}$ por cabeça por dia, misturado com ração umedecida. Pelos resultados encontrados experimentalmente, o autor concluiu que:

1 - 0 bioestimulante de tecido embrionário seco eleva, em média, $13 \%$ a postura das galinhas.

2 - 0 peso médio dos ovos das galinhas tratadas era superior a $3,4 \%$ ao peso dos ovos das testemunhas.

3 - As galinhas tratadas, não perderam peso durante o periodo de postura intensa.

4 - 0 bioestimulante de tecido embrionário seco na dose de $0,3 \mathrm{~g}$ por cabeça por dia pode ser recomendado para o aumento da postura em galinha.

$$
\text { DENOVSRI e POPHRISTOV (1969) visando verificar o }
$$

efeito dos estimulantes biogênicos sobre o conteúdo de aminoácidos no soro sanguíneo, músculos, fígado e fração protéica daquele soro em aves, forneceu a pintos de um dia, $0,3 \mathrm{ml}$ por ave uma emulsão de bioestimulante.

Os resultados demonstraram que os aminoácidos totais aumentaram no soro, fígado e müsculo, pela ação do bioes timulante. Dentre os aminoäcidos encontrados existiam alguns essenciais, como, tirosina, lisina, cistina, e metioni na. No soro, as proteínas totais, aumentaram, bem como as gamaglobulinas. 


\subsection{2 - Mecanismos de ação dos bioestimulantes}

As principais pesquisas realizadas com a finalidade de determinar o mecanismo de ação dos bioestimulantes, foram feitas por mẻdicos, utilizando principalmente animais de laboratório, e, em alguns casos, os próprios pacientes.

Alguns efeitos observados, foram os seguintes:

a - Ação vasodilatadora, devido à ação hormonal da hipófise, provocada pelas estimulinas biogênicas.

b - Determinação de um quadro de eosinopnéia e hipoglicemia, muito semelharte ao que sucede com a terapia com A.C.T. H. ou com cortisona, BOSCHI e GASPARI (1951).

c - Aumento ponderal do baço e hipertrofia dos linfonóides.

d - Aumento ponderal do cortex da supra-renal, do glicogênio e consequente hipersecreção do tipo cortisônico. Esta a ção sobre o cortex da supra-renal poderia ser direta (pre sença de A.C.T.H. no preparado) ou indireta, segundo o me canismo de "stress", PENTINI (1950).

e - Aumento da quantidade de proteinas, enzimas proteoliticas e lipolíticas no soro hemático, VANCEA et alii (1959).

f - Estimulação do sistema retículo-endotelial, com consequen te hiperleucocitose.

g- Presença de um coenzima não específico, capaz de ativar diversos enzimas especificos que acelerariam inümeras ra ções bioquímicas, VOLOSEVIC (1970.a). 
Pelos trabalhos de CHuLIOMOVA (1956) foi provado que as estimulinas biogênicas produzem inúmeros efeitos no organismo, ou seja, aumentam a reação fisiológica e imuno-bio lógica no organismo, aumentam a produção das aglutininas, hemólise, antitoxinas, etc. Faz, ainda modificar a composição morfológica do sangue, aumenta o conteúdo de hemoglobina e a quantidade de eritrócitos.

IOPA e MANOV (1958) revisando trabalhos sobre a teoria biogênica de FILATOV citaram que HARCOV, na sua tese de doutoramento, "Terapia Tissular na Cirurgia Veterinäria", cons tatou pelos testes biológicos do trabalho experimental, ação dos preparados de tecidos, no estímulo à hemopoese, verificando-se aumento de hemoglobina em 10 a $16 \%$, aumento da quantida de de eritröcito de 0,8 a 1,5 milhões, leucócitos de 3 a 6 mil, aumento brusco da reação imuno-biológica, aumento em 2 a 2,5 vezes da atividade fagocitäria dos neutrófitos e acréscimo de 3 a 3,5 vezes do indice anti-tóxico.

CARVALHo (1971) aplicou extrato de fígado de cavalo em coelhos e suínos encontrando que os seus resultados discordaram dos encontrados na literatura consultada, em relação ao quadro hemático, não se verificando nos coelhos, grandes va riações. Já nos suínos foi verificado um leve aumento dos leucócitos.

KRASILNIKOVA (1970) estudando a influência de bio estimulante de tecido seco embrionário sobre a postura de gali nhas, analisou a composição morfológica do sangue (quantidade 
total de elementos básicos, quantidade de eritrōcitos, leucócitos e tromböcitos) porcentagem de hemoglobina, a quantidade total de albumina no soro sanguíneo. Verificou que as quantidades de elementos básicos, quantidade de eritrócitos, trombóci tos diminuem ligeiramente nas aves testemunhas em comparação com os resultados obtidos antes do fornecimento do bioestimulante seco, embora a percentagem de hemoglobina, nas mesmas condições, quase não se alterou. Contudo, com o fornecimento dià rio do estimulante nas doses de 0,2 e $0,3 \mathrm{~g}$ por cabeça, a quantidade total dos elementos básicos aumentou em 254.000 e 334.000 , respectivamente, aumentando também a quantidade de a 1 bumina no soro sanguíneo em 0,76 e $1,15 \%$ e o teor de hemoglobi na em $7 \%$.

DENOVSKI e POPHRISTOV (1968), estudando o efeito de preparado de FILATOV sobre o conteüdo de aminoácidos do soro sanguíneo, músculo e fígado, e frações protēicas no soro sangui neo de pintos, encontrou aumento na quantidade de aminoácidos nos três tecidos dos animais que receberam o bioestimulante, in clusive detectou aumento de aminoácidos essenciais, como tirosi na, lisina, cistina e metionina. Foi encontrado também, no so ro, aumento da proteína total e gamaglobulina.

RIRIIIN (1968) utilizou suínos de dois a quatro meses de idade na aplicação de bioestimulante de fígado de bovi no, fornecendo uma dose de $0,1 \mathrm{mg}$ por $\mathrm{kg}$ de peso vivo, a fim de verificar a composição do sangue dos animais tratados. Não encontrou mudanças significativas de proteína total no conteúdo 
do soro sanguíneo dos animais de dois meses. Gamaglobulina aumentou de 19,49 para $28,88 \%$ em sete dias e voltou a $21,84 \%$ aos quinze dias e albumina decresceu de 40,61 para $34,92 \%$, aos sete dias, subindo novamente, aos quinze dias para $38,34 \%$. As mudanças no soro dos suínos com três meses foram similares. Nos suínos com quatro meses, a proteina total do soro não mudou significativamente. Alfa, Beta e Gama globulina aumenta ram respectivamente de 21,53 para 23,68 , de 19,76 para 21,68 e de 20,17 para $25,45 \%$ em quinze dias, tendo decrescí do a albumina de 38,54 para $29,19 \%$.

$$
\text { MIHAJLOV (1967) utilizando um preparado seco }
$$

a 459C, de embriōes de um a três meses e outro preparado de tecidos de ovário e útero seco a 7090 encontrou um aumento de glóbulos brancos e vermelhos no sangue, bem como, aumento de teor de hemoglobina e proteína total do soro, além de Beta e Gama globulina.

HAITOV et alii (1967) injetaram, em coelhos, extra tos de fígado e baço encontrando aumento do indice hemático e maior atividade dos sistemas reticulo-endotelial.

VOLOSENVICH (1972) informou que extratos de teci dos tem influência na progênie pelo seu conteūdo de aminoāci dos livres e não pela presença de hormônios sexuais. 
Os experimentos foram realizados na Escola Supe rior de Agricultura "Luiz de Queiroz", da Universidade de São Paulo, em Piracicaba, no Departamento de Zootecnia e na Granja Sumarē, em Sumaré, Estado de São Paulo. A duração experí mental, compreendendo fase pré-experimental (duas semanas) e fase experimental (18 semanas) ocorreu no período de 28 de agosto de 1975 a 23 de janeiro de 1976.

Foram utilizadas 200 galinhas matrizes e 20 galos da linhagem "Hubbard", adquiridos, por empréstimo, à Granja Sumaré. As aves tinham 53 semanas de idade no inicio do experimento sobre reprodução. Os pintos nascidos de cada quar ta incubação dos ovos das reprodutoras foram utilizados nos experimentos sobre crescimento. 
As matrizes receberam programa de luz a partir da oitava semana, mas na fase experimental não foi fornecido luz artificial. Dos 80 dias até 140 , as matrizes tiveram restrí ção alimentar que consistia em não fornecer ração às quartasfeirase domingos. Ao iniciar a postura passou-se ao regime de dia "sim" dia "näo" atë 180 dias. Da $\vec{i}$ em diante, eram fornecidas 150 gramas por dia. As aves foram vacinadas contra a doença New Castle aos 8 e 28 dias, na ägua de beber e aos 50 e 120 dias por via injetável. Daí em diante voltaram a ser vacinadas contra New Castle, a cada quatro meses. Aos 40 e 60 dias receberam tartarato de tiloeina (ELANCO) injetá vel. Foram feitos quatro testes de pulorose. As matrizes foram alojadas em casas-colônia, com piso de cimento e cama de maravalha, havendo nos alojamentos ninho tipo "açalpão" e poleiro, sendo os bebedouros e comedouros de cimento. Para c:da casa-colônia, com lotação de dez galinhas e um galo, havia um piquete gramado, onde as aves eram soltas diariamente.

$$
\text { As matrizes receberam ração utilizada e preparada }
$$
na Granja Sumaré, cabendo $150 \mathrm{~g}$ por cabeça por dia para as ga linhas e $200 \mathrm{~g}$ por cabeça por dia para os galos. Aos pintinhos a ração foi fornecida "ad libitum" sendo utilizada ração comercial para frangos de corte (Rações Anhanguera S. A.). 


\section{1 - Delineamento Experimental}

0 experimento foi realizado em parcela subdividida partindo do delineamento inteiramente casualizado, com cinco tratamentos, quatro repetições e dez matrizes e um galo por parcela. 0 tratamento 2 recebia três vezes por semana produto comercial contendo vitaminas e aminoácidos solüveis (Aminosol-Laboratórios Valinhos $\mathrm{S}$. A.) sendo a dosagem de $10 \mathrm{ml}$ do produto por dois 1 itros de ägua de beber por parcela. 0s tratamentos 3,4 e 5 separadamente receberam 1 ml de bioestimulante injetável no peito, a cada 7,14 e 21 dias de interva10, respectivamente.

No inieio do experimento as aves matrizes foram pesadas por parcela e os galos individualmente. Até o final do experimento foram feitas cinco pesagens, a cada 28 dias.

\section{2 - Preparação do Bioestimulante}

Após o recebimento das glândulas hipófises, suprarenais e testiculos de bovinos os quais permaneceram durante u ma semana em geladeira entre 09 e 4:C, houve sequenciamento de procedimentos para a preparação do extrato de tecidos, conforme métodos de FILATOV, citado por IOPA e MANOV (1958) com algumas modificações introduzidas no presente experimento. Toda gordura foi retirada do material fresco sendo este moído e 
pesado em seguida. Adicionou-se o dobro do material moído, em àgua (1:2) fervendo-se durante duas horas em banho-maria a $709 \mathrm{C}$, mexendo-se para o material não grudar no fundo do rece piente. Passou-se na peneira, espremendo-se bem o resíduo. colocou-se em bandeja secando-se em estufa de ar circulante a 709C. Quando totalmente seco, obteve-se a farinha residual. 0 líquido obtido atravēs de peneiragem foi decantado e filtrado em vácuo, pela trompa, com auxílio de um kitasato, funil e algodão, até a clarificação. Obteve-se, assim, o ex trato que foi guardado em geladeira.

\section{3 - Material Utilizado}

- Balança Hobart-Dayton (tipo Filizola) - Capacidade, $25 \mathrm{~kg}$;

- Moedor Kitchen-Aid;

- Banho-maria, temperatura controlada automaticamente a $70 \circ \mathrm{C}$;

- Estufa Thelco (ar circulante) regulada a 700C;

- Estufa secadora Fabbe (ar circulante) regulada a $708 \mathrm{C}$;

- Filtraçäo: trompa a väcuo, kitasato, funil e algo dão. 


\section{4 - Armazenamento}

- Farinha, em sacos plásticos.

- Extrato, em latas fechadas à máquina e colocadas em congelador à temperatura de $209 \mathrm{C}$ a $359 \mathrm{C}$ nega tivos.

0s extratos misturados foram guardados por 48 horas em geladeira a $89 \mathrm{C}$.

\section{5 - Preparo do Material para Pesquisa}

os liquidos depois de clarificados e filtrados fo ram divididos em duas frações. Uma delas foi enlatada e guar dada no congelador e a outra foi guardado em geladeira, após ter sido feita a seguinte mistura: extrato de testiculo, 50\%; extrato de hipófise, $25 \%$ e extrato suprarrenal, $25 \%$. Foram preparados dois litros de mistura para serem utilizados neste trabalho.

\section{6 - Esterilização e Acondicionamento}

os dois recipientes de 1 litro cada, contendo a mistura foram armazenados à temperatura de $89 \mathrm{C}$ durante qua tro dias. A mistura foi transferida para recepientes de vidro, ambos de $250 \mathrm{ml}$ e esterilizada em autoclave, Após es- 
friamento os recipientes foram lacrados com tampa de borracha e anel de aluminio e armazenados a $49 \mathrm{C}$.

\section{7 - Dados Observados}

$$
4.7 .1 \text { - Peso das aves. }
$$

As galinhas foram pesadas por parcela em engradado previamente tarado, sendo os galos pesados individualmente por parcela. Este procedimento foi repetido cinco vezes ao longo da fase experimental, a cada 28 dias.

\subsection{2 - Consumo de ração.}

Foi fornecida diariamente a quantia de $1,70 \mathrm{~kg}$ por parcela, cabendo assim, $150 \mathrm{~g}$ por matriz por dia.

\section{7 .3 - Produção de ovos.}

Diariamente eram feitas quatro colheitas de ovos, ocasião em que os mesmos eram marcados na casca, discriminando parcela e dia. 0 nümero total de ovos produzidos pelas dez aves de cada uma das dez parcelas era anotado diariamente em ficha pröpria. Os ovos abaixo de $52 \mathrm{~g}$ e acima de $75 \mathrm{~g}$ bem como os quebrados, rachados e trincados, eram descartados e anotados. Após esta operação os ovos eram pesados por parce - 
36 .

1a, obtendo-se o peso médio por parcela.

Em seguida os ovos selecionados eram fumigados, com formol e permanganato de potássio, embalados e colocados em local fresco. Apos seis dias eram transportados para serem incubados na Grazja Sumarē.

\section{$4.7 .4-$ Drosxopia}

Ao $18^{\circ}$. dia de inezbação era feita a ovoscopia, sen do eliminados, ovos claros e embrióes mortos. Em seguida eram separados por parcela e colocados em sacos de filó para identificação dos pintos nascicoos e levados à câmara de eclosão. Nessacasião os ovos eram fumigados novamente.

\section{$4.7 .5-$ Nascimento}

Aos 21 dias os pintos nascidos eram pesados por parcela e feitas as seguintes anotações: pintos refugos, pintos nascidos, ovos picados e pintos mortos. A cada quatro in cubações os pintos nascidos exam marcados com cortes nos dedos e transferidos para galinheiros onde permaneciam até 28 dias de idade para verificação do efeito de transferência ("carry-over") do bioestimulante a progênie, através do ovo. 


\subsection{6 - Mortalidade}

Era feita a anotação, no dia da ocorrência tanto de mortalidade dos reprodutores como dos pintos.

\subsection{7 - Anälises estatistịcas.}

Anālises de variância dos diversos dados coligidos foram desenvolvidos de acordo com o método descrito por PIMENTEL GOMES (1966) para um delineamento experimental inteiramente casualizado, em parcela subdividida.

Estas anälises foram realizadas com auxilio do com putador eletrônico da Escola Superior de Agricultura "Luiz de Queiroz".

Em caso de significância, as médias de tratamentos for am comparadas pelo teste de Tukey, também como recomenda o autor acima. 
38.

5 - RESULTADOS E DISCUSSÃO

\section{1 - Considerações Gerais.}

A parte experimental compreendeu duas fases, sendo a primeira relativa às matrizes onde se procurou saber: peso dos reprodutores no inicio do experimento e a cada 28 dias, té ofim do ensaio. Produção e peso dos ovos, incubabilidade total, incubabilidade dos ovos férteis e fertilidade. A segunda parte consistiu no teste do efeito "carry-over" dos pintos oriundos do nascimento a cada 28 dias, durante os quatro períodos experimentais. 


\section{2 - Produção de Ovos.}

Cada um dos valores médios apresentados na Tabela 1 , representa a média de quatro parcelas, composta de dez galinhas e um galo, durante quatro meses (periodos). As mé dias de cada tratamento e subtratamento (período) estão acom panhadas das respectivas anālises de variância.

TABELA 1 - Médias de produção de ovos por tratamentos e períodos

\begin{tabular}{cc}
\hline Tratamentos & Mëdias \\
\hline 1 & 157,812 \\
2 & 135,937 \\
3 & 141,187 \\
5 & 143,437 \\
D.M.S. (5\%) & 152,825 \\
C. V. \% & 27,193 \\
Sub-tratamento (P) & 17,037 \\
\hline 1 & 128,850 \\
2 & 131,550 \\
4 & 176,100 \\
D.M.S. (5\%) & 147,900 \\
C. V. \% & 16,484 \\
\hline D.M.S. = Diferença minima significativa & \\
C.V. \% = Coeficiente de variação & 13,381 \\
\hline
\end{tabular}


Anālise de Variância

\begin{tabular}{lrrrr}
\hline Fonte de Variaçäo & G. L. & S. Q. & Q. M. & F \\
\hline Tratamento (T) & 4 & $4.927,699$ & $1.231,924$ & 1,99 \\
Resíduo (a) & 15 & $9.293,500$ & 619,566 & - \\
Parcelas & 19 & $14.221,199$ & - & - \\
Sub-tratamento (P) & 3 & $28.250,099$ & $1.416,700 * *$ & $24,64 *$ \\
Regressão 1inear & 1 & 2,248 & $10.342,890 * *$ & 0,17 \\
Reg. Quadrätica & 1 & 48,189 & $4.774,050 * *$ & 3,74 \\
Reg. Cúbica & 1 & 9,725 & $13.133,160 * *$ & 0,75 \\
Interação T x P & 12 & $4.301,400$ & 358,450 & 0,94 \\
Residuo (b) & 45 & $17.200,500$ & 382,233 & - \\
\hline \multicolumn{1}{c}{ Total } & 79 & $63.973,199$ & - & - \\
\hline
\end{tabular}

Os tratamentos correspondentes à testemunha (1) e bioestimulante, a cada 21 dias (5) apresentaram melhores respostas, não ocorrendo o mesmo com o tratamento 2 (Aminosol). Estes resultados, todavia não foram significativos estatistica mente, concordando com resultados encontrados por GRANT e GLAS NA $N$ (1964), mas discordando das pesquisas realizadas por PALAMARU et ali $i$ (1968), BACAROVA (1966), KOVBASSENKO (1970), KRASILNIKOVA e SULJUMOVA (1971). A literatura pertinente ao assunto revela, na maioria dos casos, resultados positivos com - uso de bioestimulante. 
Houve diferença estatistica significativa ao nível de $5 \%$ de probabilidade entre as médias do terceiro e demais períodos, assim como do quarto e primeiro.

$$
\begin{aligned}
& \text { A equação } \\
& Y=282,6000-270,1750+135,5200 x^{2}-19,1000 x^{3},
\end{aligned}
$$

representativa da curva de regressão cūbica, evidencia um acréscimo de produção no primeiro e segundo períodos, um ponto mäximo no terceiro, caindo novamente a produção no quarto periodo.

Na interação tratamentos $x$ períodos, os melhores resultados foram entre, tratamento 1 xeriodo 3 e tratamen to $3 \times$ periodo 3 .

\section{3 - Peso Médio dos Ovos}

A média dos pesos dos ovos por tratamentos e perío dos e anảlise de variância estão na Tabela 2 .

As médias de peso de ovos apresentadas na Tabela 2 indicam que houve superioridade de bioestimulantes no trata mento 4 , contudo, estes resultados não foram estatisticamente significativos.

Resultados positivos também foram encontrados com uso de bioestimulante, no aumento de peso de ovos por sulJU MOVA (1971), KRASIL'NICOVA (1970), obteve 2 e $4 \%$ de peso de ovos a mais em poedeiras que receberam bioestimulante. 
TABELA 2 - Médias de peso dos ovos por tratamentos e períodos

\begin{tabular}{cc}
\hline Tratamentos (T). & Médias \\
\hline 1 & 65,574 \\
2 & 65,877 \\
3 & 65,626 \\
4 & 66,682 \\
5 & 64,050 \\
D.M.S. (5\%) & 7,910 \\
C.V. (\%) & 5,520 \\
Sub-tratamento (P) & \\
I & 64,717 \\
2 & 65,796 \\
3 & 66,881 \\
D.M.S. (5\%) & 64,855 \\
C.V. (\%) & 3,032 \\
\hline
\end{tabular}


Anảitise de Variância

\begin{tabular}{lrrrc}
\hline Fonte de Variação & G. L. & S. Q. & Q. M. & F \\
\hline Tratamento (T) & 4 & 58,440 & 14,610 & 1,114 \\
Residuo (a) & 15 & 196,667 & 13,111 & - \\
Parcelas & 19 & 255,107 & - & - \\
Sub-tratamento (P) & 3 & 60,171 & 20,057 & 1,556 \\
Regressão Linear & 1 & 2,248 & 2,248 & 0,174 \\
Reg. Quadrática & 1 & 48,182 & 48,189 & 3,739 \\
Reg. Cũbica & 1 & 9,725 & 9,725 & 0,754 \\
Interação T X P & 12 & 180,508 & 15,042 & 1,754 \\
Residuo (b) & 45 & 579,906 & 12,880 & - \\
\hline Total & 79 & & & \\
\hline
\end{tabular}

O terceiro perỉodo apresentou maior média de peso dos ovos, mas não houve significaneia estatistica. KovBASENKO (1970) encontrou maior peso no primeiro período e menores resultados nos períodos sucessivos.

ROGOZIN e RADKENEVIC (1967) deduziram pelas suas observações experimentais que "na dinâmica de aumentos na pro dução de animais que recebem bioestimulantes, os periodos de respostas baixas se alternam com os de respostas altas".

\section{4 - Incubabilidade Total}

Cada um dos valores médios apresentados na Tabela 3 compreende os resultados das incubações das 16 semanas ex- 
perimentais, excluídas três incubações perdidas devido a incidentes mecânicos no incubatório. A percentagem de incubabili dade total foi encontrada pela aplicação da fórmula:

\% Incubabilidade total $=\frac{\text { Nümero de pintos nascidos }}{\text { Número de ovos incubados }} \times 100$ 0 resultado sofreu transformação da raiz quadrada a seno do arco.

Pela análise da variância se observa que não houve diferença significativa entre tratamentos.

TABELA 3 - Médis de incubabilidade total por tratamentos e peridoos

\begin{tabular}{cc}
\hline Tratamentos & Médias \\
\hline 1 & 44,716 \\
2 & 48,037 \\
3 & 45,136 \\
4 & 46,252 \\
5 & 36,263 \\
D.M.S. (5\%) & 16,748 \\
C.V. (\%) & 34,770 \\
Sub-tratamento (P) & \\
1 & 37,039 \\
2 & 38,606 \\
3 & 50,795 \\
D.M.S. (5\%) & 49,983 \\
C.V. (\%) & 10,141 \\
\hline
\end{tabular}


Anālise de Variância

\begin{tabular}{lrrrr}
\hline Fonte de Variaçäo & G. L. & S. Q. & Q. M. & F \\
\hline Tratamento (T) & 4 & $1.328,046$ & 332,012 & 1,41 \\
Resíduo (a) & 15 & 352,307 & 235,020 & 1,41 \\
Parcelas & 19 & $4.853,353$ & - & - \\
Sub-tratamento (P) & 3 & $3.171,245$ & $1.057,082 * *$ & $7,35 * *$ \\
Regressão Linear & 1 & $2.578,710$ & $2.578,710 *$ & $17,94 * *$ \\
Reg. Quadrätica & 1 & 30,702 & 30,702 & 0,21 \\
Reg. Cǘica & 1 & $.561,832$ & 562,753 & 3,91 \\
Interação T x P & 12 & $1.496,772$ & 124,731 & 0,87 \\
Residuo (b) & 43 & $6.181,152$ & 143,748 & - \\
\hline \multicolumn{1}{c}{ Total } & 77 & $15.702,522$ & & \\
\hline
\end{tabular}

$\begin{array}{ll}(*) & P \geq 0,05 \\ (* *) & P \geq 0,01\end{array}$

Pela análise da Tabela 3 as médias de incubabilidą de total dos tratamentos 2 e 4 apresentaram-e inferiores às demais.

Estes resultados encontram concordância em BACARoVA (1966) que obteve média de $10,3 \%$ de incubabilidade total, superior à testemunha quando utilizou bioestimulante injeta vel em reprodutoras.

Tais resultados, tambëm encontram apoio nos trabaIhos de PALAmaru et alii (1968), suljumova (1968), esta, uㅡㄴ tilizando bioestimulante e suplemento de vitamina $B_{12}$, obte- 
ve $82,2 \%$ de incubabilidade versus $76,1 \%$ da testemunha. Houve diferença significativa entre os períodos: 1 e $3 ; 3$ e 4 ; 2 e 3 ; e 2 e 4 , ao nive 1 de $5 \%$ de probabiIidade.

Os periodos 3 e 4 apresentaram os melhores resultados como demonstra o teste de Tukey, o que fica evidenciado pe la regressão linear ascendente, conforme a equação

$$
Y=31,3857+5,0781 \times \text {. }
$$

As mëdias das interações tratamento versus perío dos apresentaram melhores resultados no tratamento 2 , periodo 3 e tratamento 2 , periodo 4 .

\section{5 - Incubabilidade dos Ovos Férteis}

Cada um dos valores médios mostrados na Tabela 4 a presentam condições idênticas às do ítem 5.4. Para a percentagem de incubabilidade dos ovos férteis foi empregada a fórmu 1a:

$\begin{aligned} & \text { \% de incubabilidade } \\ & \text { dos ovos férteis }\end{aligned} \frac{\text { número de pintos nascidos }}{\text { número de ovos incubados }} \times 100$

Os resultados foram transformados em arco seno. 
A Tabela 4 mostra ainda que houve um aumento nas mé dis de incubabilidade dos ovos férteis com o emprego de amino so1, (Tratamento 2) e um leve aumento com bioestimulante (Tra tamento 4). Os demais tratamentos foram inferiores. Contudo a análise da variância não apresentou significação estatís tica nem entre tratamentos nem entre periodos.

TABELA 4 - Médias de incubabilidade dos ovos férteis por tratamentos e periodos

\begin{tabular}{cr}
\hline Tratamentos (T) & Mëdias \\
\hline 1 & 62,561 \\
2 & 65,999 \\
4 & 63,788 \\
5 & 64,384 \\
D.M.S. (5\%) & 54,859 \\
C.V. (\%) & 37,350 \\
sub-tratamento (P) & 27,450 \\
\hline 1 & \\
2 & 60,486 \\
3 & 59,436 \\
4 & 66,608 \\
D.M.S. (5\%) & 62,743 \\
C.V. (\%) & 9,746 \\
\hline
\end{tabular}


48.

Anālise de Variância

\begin{tabular}{lrrrrc}
\hline Fonte de Variaçó & G. L. & S. Q. & Q. M. & F \\
\hline Tratamento (T) & 4 & $1.210,717$ & 302,679 & 1,035 \\
Residuo (a) & 15 & $4.383,443$ & $4.383,443$ & - \\
Parcelas & 19 & $5,595,160$ & - & - \\
Sub-tratamento (P) & 3 & 604,954 & 201,651 & 1,508 \\
Regressão Linear & 1 & 197,219 & 127,219 & 1,475 \\
Reg. Quadrätica & 1 & 42,442 & 42,442 & 0,317 \\
Reg. Cübica & 1 & 382,417 & 382,417 & 2,861 \\
Interação T x P & 12 & $2.486,958$ & 207,247 & 1,550 \\
Resíduo (b) & 45 & $6.014,454$ & 133,655 & \\
\hline Total & 79 & $14.700,510$ & & \\
\hline
\end{tabular}

$5.6-$ Fertilidade

A percentagem de fertilidade foi encontrada pela fórmula:

\% Fertilidade $-\frac{\text { Nümero de ovos fērteis }}{\text { Número de ovos incubados }} \times 100$

e os resultados foram transformados em arco seno.
A Tabela 5 apresenta
as
médi as
de fer

tilidade e a análise de variância dos dados coletados durante - periodo experimental. Apesar de não ter havido efeito de tratamentos, os tratamentos 4 e 2 apresentaram médias acima dos demais. Houve diferença significativa entre os períodos: 
1 e 2 ; 1 e 3 ; e 2 e 3 , ao nivel de $5 \%$ de probabilidade. A equação de regressão ascendente

$$
x=37,6132+4,2684 x
$$

evidencia mäxima fertilidade no terceiro período.

$$
\text { JULENKO (1958) citado por BOCAROVA (1966) encontrou }
$$

resposta positiva na fertilidade em aves que receberam três dọ ses de $4 \mathrm{ml}$ de bioestimulante em dias alternados, informando também que doses maiores provocaram efeitos adversos, afirmando ainda que mais estudos seriam necessārios sobre o assunto.

Neste trabalho as doses foram quatro vezes menores mas o intervalo mais longo. BOCAROVA (1966) utilizando 2 ml do preparado em matrizes encontrou diferença de fertilidade a I tamente significativas. Este autor concluiu ainda que a dose de $6 \mathrm{ml}$ por ave diminuia a fertilidade. No presente experimento notau-se alguns problemas de fertilidade com os galos. Procurou-se corrigir fazendo um rodizio de galos por repeti çöes do mesmo tratamento. Contudo näo foi encontrado na lite ratura consultada, procedimento semelhante, de forma que este fato pode ter influenciado nos resultados de fertilidade. 
TABELA 5 - Médias de fertilidade dos ovos por tratamentos e períodos

\begin{tabular}{cc}
\hline Tratamento (T) & Médias \\
\hline 1 & 46,272 \\
2 & 51,090 \\
3 & 49,973 \\
4 & 52,296 \\
5 & 41,788 \\
D.M.S. (5\%) & 38,900 \\
C.V. (\%) & 36,870 \\
Sub-tratamento (P) & \\
\hline 1 & 43,249 \\
2 & 41,746 \\
3 & 55,150 \\
D.M.S. (5\%) & 53,000 \\
C.V. (\%) & 11,880 \\
\hline
\end{tabular}


Anälise de Variância

\begin{tabular}{lrrccc}
\hline Fonte de Variação & G. L. & Q.M. & Q.M. & F \\
\hline Tratamento & 4 & $1.169,009$ & 292,252 & 0,921 \\
Residuo (a) & 15 & $4.754,848$ & 316,989 & - \\
Parcelas & 19 & $5.923,857$ & - & - \\
Sub-tratamento (P) & 3 & $2.751,409$ & $917,136 *$ & $4,615 * *$ \\
Regressão Linear & 1 & $1.821,923$ & $1.821,923 * *$ & $9,168 * *$ \\
Reg. Quadrätica & 1 & 2,158 & 2,158 & 0,010 \\
Reg. Cúbica & 1 & 927,324 & $927,324 *$ & $4,666 *$ \\
Interação T x P & 12 & $1.448,091$ & 120,674 & 0,607 \\
Residuo (b) & 45 & $8.942,656$ & 198,725 & - \\
\hline Total & 79 & $19.066,007$ & & \\
\hline
\end{tabular}

$\begin{array}{ll}\text { (*) } & P \geq 0,05 \\ (* *) & P \geq 0,01\end{array}$

\section{7 - Médias de Peso dos Galos em Intervalos de 28 Dias}

Cada um dos valores médios apresentados na Tabela 6 representa as mëdias de cinco pesagens. A primeira pesagem noi feita no inicio do experimerto e as restantes a interva los de 28 dias até o final do ensaio.

Pelo exame da Tabela 6 , nota-se não ter havido feito de tratamentos nem de periodos. Observa-se todavia, que as mais altas médias de pesos se verificaram, por ordem, nos Tratamentos 5,4 e 3 (bioestimulante), enquanto que a testemunha e o Tratamento 2 (nminosol) se mostraram mais ba xos. Quanto a periodos, o quarto se moscrou com mëdias mais 
elevadas.

Resultados positivos com uso de bioestimulante foram encontrados por VORONEDOV e NEFEDOV (1966), OE et ali (1966), PALAMARU et alii (1968), SULJUMOVA (1971) e KOVBA SENKO (1969), diferentes, portanto dos encontrados pelo autor.

TABELA 6 - Médias de pesos dos galos com intervalos de 28 dias

\begin{tabular}{cc}
\hline Tratamento (T) & Médias \\
\hline 1 & 1,024 \\
2 & 0,943 \\
3 & 1,051 \\
4 & 1,036 \\
5 & 1,086 \\
D.M.S. (5\%) & 0,214 \\
C.V. (\%) & 19,084 \\
Sub-tratamento (P) & 1,021 \\
\hline 1 & 1,021 \\
3 & 1,019 \\
4 & 1,051 \\
D.M.S. (5\%) & 1,116 \\
C.V. (\%) & 19,080 \\
\hline
\end{tabular}


Anālise de Variância

\begin{tabular}{lcccc}
\hline Fonte de Variaça & G. L. & S. Q. & Q. M. & F \\
\hline Tratamento (T) & 4 & 0,180 & 0,045 & 1,172 \\
Residuo (a) & 15 & 0,577 & 0,038 & - \\
Parcelas & 19 & 0,757 & - & 0,247 \\
Sub-tratamento (P) & 3 & 0,013 & 0,004 & - \\
Regressão Linear & 1 & 0,007 & 0,007 & 0,419 \\
Reg. Quadrätica & 1 & 0,004 & 0,005 & 35,353 \\
Reg. Cübica & 1 & 0,001 & 0,001 & 0,059 \\
Interação T x P & 12 & 0,055 & 0,004 & 0,247 \\
Resíduo (b) & 45 & 0,846 & 0,018 & - \\
\hline Total & 79 & 1,674 & & \\
\hline
\end{tabular}

5.8 - Médias de Peso das Matrizes em Intervalos de 28 Dias

Cada um dos valores médios apresentados na Tabela 7 representa igualmente a média de cinco pesagens, a cada intervalo de 28 dias.

Observando a Tabela 7 , notamse que o bieestimulan te utilizado nos diversos tratamentos proporcionou melhores pesos, enquanto que a testemunha e Tratamento 2 (aminosol) apresentaram os menores ganhos de peso das matrizes. Mesmo assim estes resultados não foram estatisticamente significativos, conforme se pode observar pela anälise de variância. 


$$
54 .
$$

KRASILNIKOVA (1970) encontrou aumento de $100 \mathrm{~g}$ por cabeça em matrizes que receberam bioestimulante, informando ainda que mesmo durante o período de intensa postura as aves não perderam peso o que não sucedeu com a testemunha.

Houve diferença significativa entre as médias dos períodos 1 e 2 , e 1 e 4 a o nível de $5 \%$ de probabilidade. A equação quadrática

$$
Y=0,82690+0,28320 X-0,04950 x^{2}
$$

indica que a maior média de peso das matrizes ocorreu bem próximo do terceiro período.

TABELA 7 - Médias de peso das matrizes em intervalo de 28 dias

\begin{tabular}{cc}
\hline Tratamentos (T) & Médias \\
\hline 1 & 1,075 \\
2 & 1,151 \\
3 & 1,163 \\
4 & 1,158 \\
5 & 1,134 \\
D.M.S. (5\%) & 0,225 \\
C.V. (\%) & 18,100 \\
Sub-tratamento (P) & 1,061 \\
1 & 1,193 \\
2 & 1,123 \\
3 & 1,167 \\
4 & 0,095 \\
D.M.S. (5\%) & 18,100 \\
\hline C.V. (\%) & \\
\hline
\end{tabular}


Anạl ise de Variância

\begin{tabular}{lcccc}
\hline Fonte de Variação & G. L. & S. Q. & Q. M. & F \\
\hline Tratamento (T) & 4 & 0,082 & 0,0207 & 0,4882 \\
Residuo (a) & 15 & 0,634 & 0,0423 & - \\
Parcelas & 19 & 0,716 & $0,0661 * *$ & - \\
Sub-tratamento (P) & 3 & 0,198 & $10,1021 * *$ & $5,240 * *$ \\
Regressão Linear & 1 & 0,127 & $15,5374 * * 10,102 * *$ \\
Reg. Quadrática & 1 & 0,196 & 0,0202 & $15,537 * *$ \\
Reg. Cūbica & 1 & 0,0002 & 0,0130 & 0,079 \\
Interação T X P & 12 & 0,155 & 0,0126 & 1,028 \\
Residuo (b) & 45 & 0,567 & & \\
\hline Total & 79 & & & \\
\hline
\end{tabular}

$\begin{aligned}(*) & P \geq 0,05 \\ (* *) & P \geq 0,01\end{aligned}$

5.9 - Médias de Peso da Progênie nos 28 Dias de Idade

Conforme demonstra a Tabela 8 não houve efeito de tratamentos quanto ao peso inicial da progênie. Estes resultados estão em desacordo com os anteriormente encontrados por PITZHEALAUR I e TCHIKADZE (1966), BOCAROVA (1966) que obtiveram resultados significativos no peso da progênie quando forne ceram bioestimulante a matrizes.

No presente trabalho encontrou-se, aproximadamente, $7 \%$ de diferença entre os tratamentos 2 e 4 .

Foram encontradas diferenças significativas entre as médias dos periodos 1 e os demais 2 e 33 e 4 , ao nî 
vel de $5 \%$ de probabilidade.

$$
\begin{gathered}
\text { A curva da equação de regressão cübica } \\
Y=1.608,3691-1.657,02492 X+706,48125 X^{2}-92,60483 x^{3}
\end{gathered}
$$

mostra que o peso minimo ocorreu próximo ao período 2 e o máximo, pouco depois do período 3 , com um ponto de inflexão do segundo para o terceiro período.

TABELA 8 - Médias dos pesos da progênie aos 28 dias de idade

\begin{tabular}{cc}
\hline Tratamentos (T) & Médias \\
\hline 1 & 460,320 \\
2 & 436,719 \\
3 & 441,767 \\
4 & 466,297 \\
5 & 441,342 \\
D.M.S. (5\%) & 47,520 \\
C.V. (\%) & 7,310 \\
Sub-tratamento (P) & \\
\hline 1 & 565,214 \\
2 & 379,390 \\
3 & 495,289 \\
D.H.S. (5\%) & 357,254 \\
C.V. (\%) & 37,872 \\
\hline
\end{tabular}




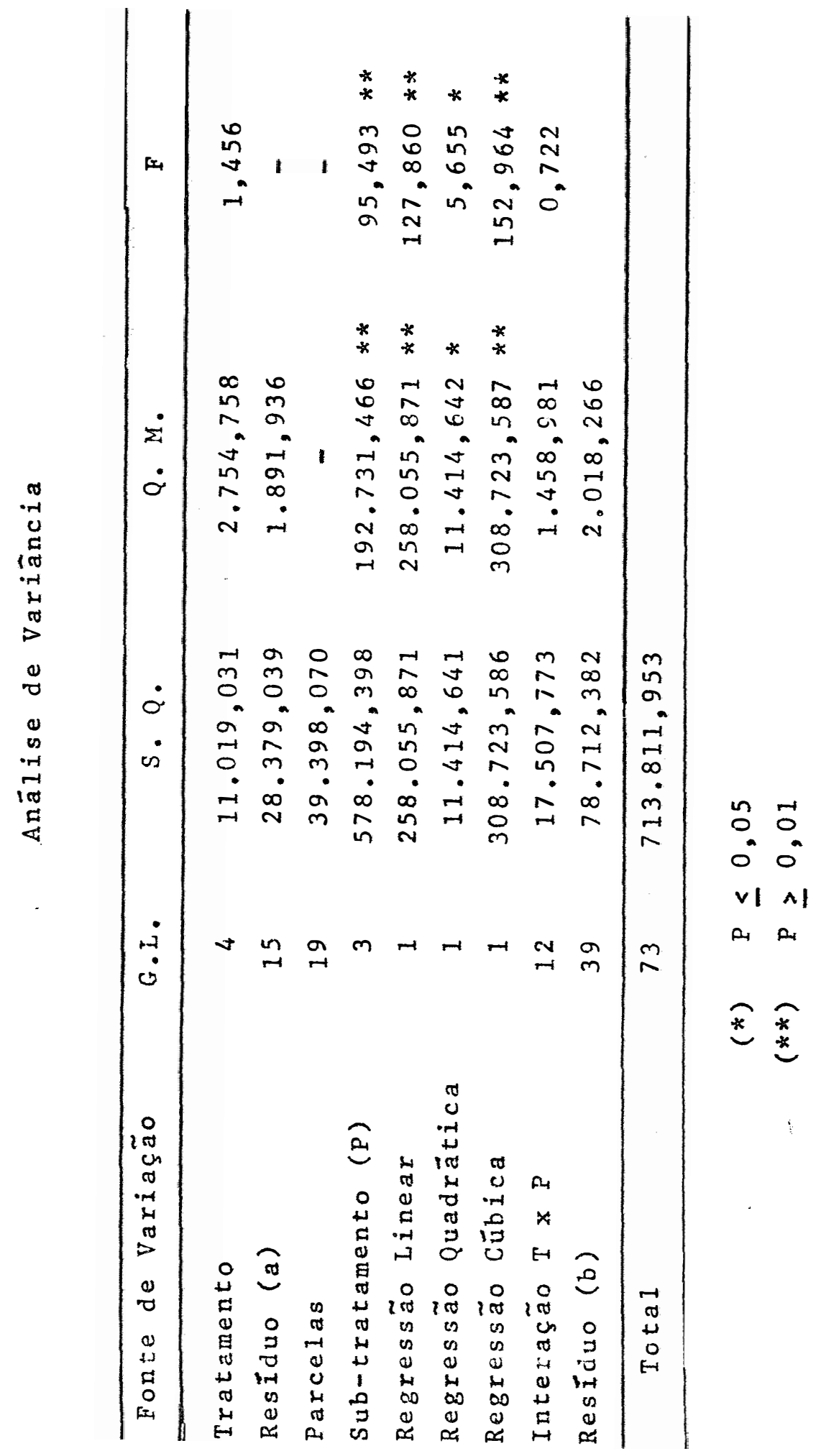


58.

6 - CONCLUSÖES

Nas circunstâncias em que se realizou o experimento e pelos dados obtidos pode-se concluir o seguinte:

1 - A produção de ovos não foi afetada com a utilização de bioestimulantes. Hã, contudo, diferenças de produção en tre períodos quando da aplicação dos produtos.

2 - Os bioestimulantes afetaram positivamente o peso dos ovos apesar de não apresentarem significância estatística.

3 - Não, foram observadas diferenças significativas entre tratamentos na incubabilidade total. Contudo houve signifi cação estatistica quanto a periodos.

4 - As médias de incubabilidade dos ovos férteis e fertilidade foram melhores com o uso de aminosol e bioestimulante. Este tambēm promoveu meltoras nos aumentos médios de pesos de galos e matrizes. Todavia as anälises de variância não demonstraram significâncias estatísticas. 
Os dados das análises revelaram que houve significação estatística entre médias de períodos ao nível de $5 \%$ de probabilidade.

As médias de pesos iniciais da progênie não apre sentaram efeitos de tratamentos, contudo houve efeitos de periodos $(P \geq 0,05)$. 
60.

\section{7 - SUMMARY}

This work deals with the study of the effect of biostimulant (FILATOV'S preparation) on the reproduction of broiler breeder hens and on the initial growth of the progeny. This experiment was carried out at the "Escola Superior de Agricultura "Luiz de Queiroz", University of São Paulo, in Piracicaba, State of São Paulo, Brasil. The preexperimental phase lasted for (2) two weeks, and the experimental phase for (18) eighteen weeks. Both were from August 28, 1975 to January 23, 1976 .

Two hundred (200) breeder hens and (20) twenty roos ters from the Hubbard line were used. The chicks born from each $4^{\text {th }}$. incubation of the eggs were used in the growth phase. The hens recieved 150 g. per head per day and the roosters $200 \mathrm{~g}$. per cay of breed: ration. The baby chicks recieved starter ration "ad libitum". 
The experiment was designed according to a split plot on time with 5 treatments, 4 replications completly rondomi zed with (10) ten hens and (1) one rooster. The treatment n: 1 was used as test, thus receving nothing. Treatment no 2 was given 3 times a week soluble vitamins and aminoacid (Amino sol) with doses of $10 \mathrm{ml}$ of the product per liter of water, per unit. Treatments nos 3,4 and 5 separatly received 1 m of biostimulant which was injected in the breast of the chickens at intervals of 7,14 and 21 days, respectively.

In the beginning of the experiment and every 28 days, the birds were weighted. The biostimulant was prepared with pituitaries, adrenals and bovine testicles according to the method devised by FILATOV. The eggs produced were collected 4 times a day, weighted and fumigated. On the $18^{\text {th. }}$ day a testing of fertility was made. The day old chicks born were weighted on an experimental unit basis. Eggs that did not hatch, dead chicks and rejected ones were recorded on the $21^{\text {th }}$. day.

Eg8 production, egg weight, fertility and body weight of breeder hens and roosters were not affect by the treatments used in this experiment. However, those traits showed a significant $(P \geq 0,05)$ effect of period of production. Body weight of progeny at the age of 28 days was not influenced by the treatments applied in the hens. 
BERGSTROM, S. e B. SAMUELSON, 1965. Prostaglandins. In: An nual Review of Biochemistry, Annual Review Inc. . S. Francisco, California, USA, p. 101-107.

BOCAROVA, I. G., 1966. Preparations "SB" as a stimulator of productivity of fowls. Anim. Breeding Abst. Edinburgh, 36: 198 .

BOCAROVA, I. G., 1967. Experiments on the use of the hetero protein preparation "SB" in poultry breeding. Anim. Bree ding Abst. Edinburgh, $\underline{36}$ : 508 .

BOSCHI, E. e A. GASPARI, 1951. Contributo allo studio della terapia tissulare e identità d'azione degli estrati placen tari e degli ormoni corticosurrenali e corticostimulanti in corso di terapia antiartritica. Rev. Ist. Sier. It. Roma, 26: 447-460. 
CARVALHO, R. T. L., 1971. Indagine sull'impiego di biostimo lanti dell'accrescimento nell'allevamento dei conigli e dei maiali. Milano, Facoltá di Agraria Universitá di Mi lano, Italia, $52 \mathrm{p}$.

CHULIUMOVA, R. C., 1956. A aplicação de preparados de tecidos e alguns dados experimentais referentes a sua atividade durante o crescimento e engorda de diversos animais jovens. In: Teses da Conferência sobre Alimentação Racional e Criação (Trad. Russa), Moscou, p. 123-125.

DENOVSKI, D. e A. POPHRISTOV, 1969. Effect of biogenic stimu lants on amino acid contents of blood serum muscles and liver and of the protein fractions of blood serum in chickens. Nutr. Abst. Edinburgh, 40: 889 .

DOROSKOV, V. B., 1962. Biological activity of placenta tissue preparations. Zivotnovodstvo, Moscou, 24: 33-35.

FAO, 1969. Report Series n? 45. Twelfth report of the Joint FAO-WHO. Expert Comittee on Food Additives. Geneve. p. 49.

GONDOS, M. ; E. PALAMARU; M. SIRIBU; P. GHIMPU; F. SAGHIN e V. MAXIMIM, 1968. Efectul unor suporturi folosite la fabricarea biostimulatorilor pentru passari. Lucrarile stiintifice. Bucuresti XXVI: 463-471.

GONDOS, M. E. ; E. PALAMARU; S. MARIA; H. ElENA; A. HARISIAN; P. GHIMPU; S. FELICIA e M. VENTURIA, 1968. Eficienta Unor Biostimulatori pe baza de suporturi diferite in hrana porcinelor, Lucrarile Stiintifice. Bucuresti, XXVI. 353-363. 
GORLOVA, V. K., 1971. The effect of various doses of the hor mones and dried tissue preparations in the rearing of broi1ers. Anim. Breeding Abst. Edinburgh, 39: 375 .

GRANAT, J. ZELNIK e V. GLASNAK, 1964. The effect of biogenic stimulators on the growth rate of cockerels during fattening. Anim. Breeding Abst. Edinburgh, 33: 515 .

GUILlAUME, J. e C. CALET, 1972. Les substances ajoutées aux aliments des volailes. Bull. Soc. Sci. H. Alim, Paris, 60: $189-206$.

HAITOV, R. H. ; L. K. GARUMJANC e N. G. BOCKAREV, 1967. The effect of tissue preparations on the body of rabbits. Anim. Breed. Abst. Edinburgh, 35: 479 .

HAITOV, R. H. ; A. B. LEBEDEV e M. G. BOCKAREV, 1967. The effect of tissue preparations on weight of calves. Anim. Breed. Abst. Edinburgh, 35: 2.346 .

IOPA, I. S. e G. M. MANOV, 1958. The use of Academician V. P. Filatov's tissue preparations on livestock farms in the Razan district. Veterinarija. Moscou, 10: 25-29.

JAAP, G. R., 1935. Gonad-stimulating potency of individual pituitaries. Poultry Sci. Iowa, 14: 237-246.

RALASNIK, I. A., 1960. Preserved animal blood as biogenic stimulant for fattening pig. Nut. Abst. Rev. Edinburgh, 30: 5.011 .

RIRILIN, V. V., 1968. Tissue preparations and protein compo sition of the blood in pigs. Svinovodstvo. Moscou, 12: $19=20$. 
KIYOSHI, I., 1973. Effects of avian and mammalian pituitary preparations on induction of ovulation in the domestic fowl, Gallus domesticus. J, Reprod. Fert. Edinburgh, 33: $91-98$.

KOROL'KOV, V. I. e N. V. PETRISIN, 1960. Preserved testicular tissue for boars stimulates weight gains of pigs. Nut. Abst. Rev. Edinburgh, 30: 5.013.

KOVBASSENKO, V. M., 1968. The effect of some stimulators (dried tissue preparation, vitamin $B_{12}$ concentrate and their combination whith antibiotics) on commercial and breeding quality of fowl eggs. Anim. Breed. Abst. Edinburgh, 39: 374 .

KOVBASSENOK, V. M., 1969. Variation in external characters of Russian white cocks under the influence of dried tissue preparations and biomycin in their diet. Anim. Bredd. Abst. Edinburgh, 39: 375 .

KOVBASSENKO, V. M., 1970. Variations in the quality of eggs and meat from layers due to a stimulating dose of a preparation of dried tissue from non edible animal offal. Anim. Breed. Abst. Edinburgh, 40: 369 .

KRASILNIKOVA, A. I., 1970. The effect of dry biostimulator from embrionic tissue on egg laying in hens. Anim. Breed. Abst. Edinburgh, 40 : 369 .

MARAKOV, P.A. e S. I. SOLOV'EN, 1962. An agar-tissue preparation for fattening animals. Nutrition Abst. Rev. Edin burgh, 33: 563 . 
66.

MARGARET, E. M., 1967. The effects of avian gonadotrophin precipitate on pituitary deficient hens. J. Reprod. Fert. 14: $257-263$.

MARY, J. e R. G. GUSTAVSON, 1930. The production of female genital subsidiary characters and plumage sex characters by injection of human placental hormone in fowls. J. Exp. Zool., 56: $31-50$.

MIHAJLOV, P. A., 1967. Tissue preparations increase weight gains. Nutr. Abst., Edinburgh, 37: 1.259.

OE, K.; M. SASAKI; S. EBI; K. HIRANO e Y. SAKUMA, 1966. The effect of artificial thyroid substance on broiler and pig growth. 1. The effect on the growth of broilers. 2 . The effect on growth and fattening of pigs. Bul1. Coll. Agri. Vet. Med, Nihon, 22: 2-15.

PALAMARU, E.; M. GONDOS; M. SIRIBU;. BORCESCU; M. ERDEI; S. ROMANOVSCHI; P. GHIMPU e F. SAGHIN, 1968. Ridicarea productiei la pásāri prin folosirea unor substante biostimulatore. Lucrarile Stiintifice. Bucuresti, XXVI: 449461 .

PALAMARU, E. ; M. GONDOS; M. SIRIBU; N. BORCESCD;A. NICHITIN ; D. IONESCU; P. GHIMPU e V. MAXIMIM, 1968.a Cercetare privind eficacitatea unor biostimulatori indigeni la porci. Lucrarile Stiintifice. Bucuresti, XXVI: $341-352$.

PENTINI, G., 1950. Estrati placentari. Atti S.0.I., Roma, XIII: $\quad 503-507$. 
PETRUSKIN, A. A. e P. F. DAHKILJGOVA, 1961. Tissue preparations in animal production. Veterinarija. Moscou, 37: $27-28$.

PHARRIS, B. B. e J. E. SHAW, 1974. Prostaglandins in reproduction. In: Annual Review of Physiology, Annual Review Inc. S. Francisco, California, p. 391-441.

PIMENTEL GOMES, F., 1966. Curso, de Estatistica Experimen_ta1. 3. ed., ESALQ, Piracicaba, SP. 404.

PITZHEALAURI, B. K. e V. V. TCHIKADZE, 1966. Experimento re ferente à aplicação de preparados de tecidos na avicultura. Aplicação de preparados de tecidos na pecuāria e veterināria. In: Dados da II Conferência Científica de Produção (1964). Kiev.

REBREANU, L.; A. CINDEA; S. POPOVIC e M. GROSU, 1966. Stimulatory effect of liver tissue extracts on weight gain in 6 to 12 months of cattle. Anim. Breed, Abst. Edinburgh, 37: 3.431 .

ROGOZIN, S. P. e P. F. RADKEVIC, 1967. The use of anabolic hormones and dried tissue preparations in the rearing of broilers. Anim. Breed. Abst. Edinburgh, 37: 142 .

SHALATOV, P. I., 1964. Preparation and use of defibrinated or citrated brood of pregnant mares in cattle breeding. Atti V. Congr. It. Riprod. Anim, Trento, VI: 89.

SOKOLOVA, G. S., 1971. The effect of growth stimulators on productivity of poultry. Edinburgh. Anim. Breed. Abst. 39: 375 . 
SULJUMOVA, F. S., 1971. The effect of dried tissue preparations, vitamin $B_{12}$ concentrate and their combination with antibiotics on egg producion of hens and devlopment of chicks. Edinburgh. Anim. Breed. Abst., 39: 363 .

TOROSJAN, S. E., 1959. Effect of biogenic stimulants or the growth of suckling pigs. Svinovodstovo. Moscou, 12: 41-45.

VANCEA, G.;A. BATCU; I. SERBAN e G. POSPECU, 1959. La the rapeutique tissulaire. Annuaired ${ }^{\circ} 0$ culiste. Paris, 192: $433-44$.

VOLOSEVICH, 0. P., 1972. Sex control in the progeny of lives tock. Edinburgh. Anim. Breed. Abst., 40: 220.

VOLOSEVICH, 0. P., 1972. a Sex control in cattle. Anim. Breed. Abst. Edinburgh, 40: 395 .

VORONEDOV, V.S. e N. A. NEFEDOV, 1966. Biogenic stimulators in the fattening of cockerels. Anim. Breed. Abst. Edin burgh, 34: 562 .

WOOD, W. A. e A. N. WORDEN, 1963. Effect on performance of a supplement comprised largely of glandular tissue (hormone$x a)$ in the diet of rats, rabbits and chicks. J. Sci. Fd. Agric. 14: $904-910$.

XAITOV, R.X.; L. K. GARUMIANZ e H. G. BOTCHKARIOV, 1964 . Influência dos preparados de tecidos sobre o organismo dos coelhos. Aplicação dos preparados de tecidos na pecuária e veterināria. Kiev. In: Dados da II Conferência Cientí fica de Produção, 1966. 
ZABOLOTNYS, I. I., 1958. Preparations of liver and spleen as growth stimulants for young pigs. Moscou, Veterinarija, 35: 65-75.

ZINTCHENKO, A. V., 1964. Influência dos preparados de tecí dos sobre os ganhos de peso de suinos durante a engorda. Aplicação de tecidos na pecuária e veterinária. Kiev. Dados da II Conferência Científica de Produção, 1966. 